\title{
Unimaginable hence unmanageable: new names for invisible urban places
}

\author{
Corrado Poli* ${ }^{*}$
}

\begin{abstract}
A name cannot change the city and our relationship with places. However, new terms for now-nameless spaces will help to change people's perception and their capability of seeing what they have never seen before. The geographer's taxonomic effort to re-designate urban places and typologies involves a political and ideological content. Most urban spaces are unmanageable because they fit neither with current technology nor with the social organization. Urban design requires new interpretations of and ideas about the awareness and form of settlements. Elaborating on what we learnt in the past is no longer enough to kindle creativeness and innovation. In the tradition of classic geography, I call for a new classification of urban places, which is meant to find names for places we do not "see" and therefore we cannot catalogue. A new classification of human settlements is a step forward on a new path to perceive, define and eventually plan them. A new perception of metropolitan areas leads to a different relation between area and administration; hence between urban places and representation of citizens.
\end{abstract}

Keywords: Urban geography, Planning, Space perception, Creative writing, City politics

\section{Background}

This article deals with four issues that are rarely related to each other in geographical and urban planning studies: language, economics, social studies and government. The elaboration of the four issues is preceded by some considerations about geography as a discipline which is meant to return to its etymological meaning, namely "the description of the Earth". It includes the proposal to use a literary writing style rather than present a fully-structured study in social science.

Part One ("Geographical studies and the city") concerns the geographical method which brings me to call for an innovative description of contemporary urbanization. In the past, new urban definitions were introduced when the human settlement pattern changed and some creative geographer eventually recognized (or devised) the new situation. We might be on the brink of a new urban revolution and an interpretative effort would help to manage (or even to prime) the transition. The disciplinary context in which cultural and physical changes

\footnotetext{
*Correspondence: policorrado@gmail.com

Journalist and Licensed University Professor Of Geography (Asn-Italy), Via Gerardo 18E, 35127 Padova, Italy
}

happened is also described in this section. Finally, I propose some possible research directions for planning and governing the cities of tomorrow.

In Part two ("Reality and perception of urban settlements"), I expose my thesis about the dramatic change occurred in physical urban settlements and in the inhabitants' subjective perception of the areas in which they live and move. Consequently, new definitions and new names to define places would orientate people and city planners in now-unknown and undefined environments.

Part three ("Economics and governance in metropolitan areas") deals with the political and economic forces that shape cities and transform them into endless suburbs. The basic question is: can we really govern metropolitan areas, as they are with the tools that we developed in the past for a completely different environment? There is no answer yet and we are still very far away from having one.

Thus, the article ends (Part four: "The geographer's solution") by proposing to begin with just a little step forward: renaming places, which includes a major intellectual effort in analysis and interpretation. Lao Tzu uttered that "every long journey begins with a single step". But Seneca warned him by pointing out that "there is no 
favorable wind to the sailor who doesn't know where to go". This article is the first single step toward an identified destination.

\section{Part one: geographical studies and the city Back to classic geography}

Describing, interpreting, and renaming urban places and typologies is the very task of human geography as a discipline. Geographers create new spaces by naming them. Also, geography is the art of narrating the earth so that we may suggest that it includes some sort of literary and imaginative writing. This approach to geography has a long and noble tradition. Herodotus, Marco Polo, the explorers who recounted their journeys to unknown lands, and the eighteenth century Grand Tours' celebrated writers such as Lord Byron and Wolfgang Goethe who anticipated several contemporary writers who still tell us about old lands and turn them into new places. Mindful travelers can see what distracted wayfarers disregard as they lack curiosity and observation skills. If you don't believe it is God's Grace that lets the blind see, it is certainly culture and some training in geography. In some respect, geography is the "conscience of the eye", if we want to borrow a famous title by Richard Sennett's (1990).

In the last half-century or so the classic geographical approach hasn't been very popular in scholarly essays, nor in literary writing, but it is regaining a new attention under the pressure of necessity. Geography renews itself as a human and creative discipline-rather than a sociological or philosophical one-because we need to see and designate places that have disappeared and thus become unknown. A major International conference was held in Florence on June 27-28, 2016 about "CrossDisciplinary Urban Space". It was organized by the University of Florence and the University College Cork (Ireland). Participants and lecturers came from all over Europe, North and South America. Notwithstanding the high quality and the wide disciplinary range of the presentations, an attempt to shift from description to a systematic approach still lacks (Cross Disciplinary Urban Space 2016). In this essay, I call for future research aiming at creating a new workable urban taxonomy. A similar need cyclically emerges when radical urban transformations take place. In modern times, we can recall the growth of metropolises analyzed by Simmel, Durkheim and by planners such as Howard and Geddes, not to speak about celebrated writers who grasped the feeling of the new urban world decades in advance such as Samuel Johnson with his famous description of eighteenth century London. We may also add Baudelaire's poetry about fin de siècle Paris (Berman 1982), not to speak of painters, film-makers and visual artists amazed by modern and postmodern cities which they often saw from imaginary perspectives. Geographers like Peter Hall (1966) identified polycentric "world cities" and Jean Gottmann (1961) coined the term Megalopolis to describe an unprecedented urban settlement. It is no longer enough to accept definitions and conventional visions of urban reality: the appellations assigned to urban places refer to a vanished urban environment. New eyes and a different outlook are necessary to see what is going on in our cities. Otherwise we are biased by fossilized perceptions and keep applying new technologies to old social organization and to the existing physical structures.

\section{Historians and geographers vs. social scientists}

Some geographers think like historians, namely differently from social scientists that have dominated territorial studies in the most recent decades. These geographers, as well as historians, adopt a so-called "idiographic" or exceptionalist approach: they study what was, is or will be unique. Social scientists typically apply a "nomothetic" approach, which aims at finding regularities. The former propose generalizations, the latter establish laws. Thus, the geographer's task is to see and describe in advance what no one has ever seen before in as much as the social scientist projects into the future regularities that happened in the past. Geographers areor should be-trained to see and describe: they are writers, historians and their primary task is explanation. ${ }^{1}$ In this respect, their scholarly approach is similar to the study of history. Because history and geography study the uniqueness of events, they are more predisposed than social sciences to foresee the future and to make it possible. $^{2}$

This is a basic epistemic issue that distinguishes social science from history. The missing of this distinction is responsible of the ineffectiveness of several urban plans

\footnotetext{
1 Two famous geographers have influenced my education. When I was at The Johns Hopkins University I attended David Harvey's courses. Previously I had studied geography in Italy and later at Berkeley with Peter Hall. Harvey (1969), before becoming a Marxist theoretician wrote a fundamental essay on "Explanation in Geography". As a young man, Hall was a geographer and a brilliant writer; he went on to become a planner and a political analyst without abandoning his elegant writing skills. His essay Cities of Tomorrow is indeed a history about how late-eighteenth and early-nineteenth centuries planners imagined the city of the future (Hall 1988).

2 Nobody has a direct experience of the past; therefore, what happened in the past can only be interpreted. The future hasn't yet happened, hence we can change it, no matter what predictions and projections foresee. Because the future depends on human will and freedom, and is unpredictable, hence deterministic "laws" applied to human history are unlike to foresee the future and even less to create it. Of course, if you don't accept that the future depends on human will, you may believe that social (scientific) laws govern the development of history and geography. Classic Marx materialism goes in this direction. This is a recurrent controversy between the actor and the system that worried and worries so many social scientists (See, e.g., Habermas and Luhmann 1971, Crozier-Friedberg 1980).
} 
and of the incapability to understand and manage longterm change. The term "laws" belongs to the scientific domain and bears a deterministic content. Social science tries to detect a group of events that are associated in a cause and effect mode. Social science helps to make decisions in the short and middle term, but its suitability to interpret long term developments is questionable. "Generalizations" are typically proposed by historians and geographers. In history, scholars may identify possible and/or cyclical recurrences of similar events; in geography, they describe possible (not compulsory) links with some physical and social features and human behavior. This distinction lies at the foundation of postpositivist geography and history that was theorized by French historians Lucièn Febrve and Max Bloch, the founders of the Annales d'histoire économique et sociale many decades ago. I also found the same distinction in Gerschenkron (1962) studies about economic development. Another interesting and vibrant polemic took place between Nobel Prize Gunnar Myrdal and the influential economist Walter Rostow about development stages (Myrdal 1968, Rostow 1960, reported in Poli 2015). A decade ago, this issue has been opportunely reexamined in the Annals of the Association of the American Geographers (see Siu 2004; Smith 2004; Goodchild 2004). ${ }^{3}$

This essay is a call for a return to historical and geographical studies as a fundamental background for policymakers and planners. ${ }^{4}$

\section{The name of the city: two scenarios}

We need a radical change to face the most compelling contemporary urban problems. In fact, most urban spaces are unmanageable and fit neither with current technology nor with the social organization. A possible scenario is a worsening of the ongoing decline that will likely cause governments to make ineffective attempts to control metropolitan wasteland by using police force to impose a(n) (il)legitimate authority. Another more optimistic scenario shows a radical reshaping of urban physical and social spaces based both on soft environmentally-friendly technologies and on a more just society. Urban design requires new interpretations of and ideas about the perception and form of settlements. The

\footnotetext{
${ }^{3}$ Of course, I don't forget Popper's neo-positivism but I am more akin to radical epistemologists such as Kuhn, Lakatos, Feyerabend and the Berkeley school which somehow includes the physicist-philosopher and environmentalist Fritjof Capra and scholars in system analysis, e.g. Bateson.

${ }^{4}$ Some of the considerations reported in this essay constitute the background of the International Master Course in Sustainable Urban Management: Communication, Economics and Social Science for Creative Managers and Administrators, which I designed for IULM University, Milan, Italy and elaborated in my Environmental Politics (Poli 2015).
}

process of change has a chance to begin if sustained by an active intellectual elaboration that frames future solutions in government, technology and design in urban areas of tomorrow. The current logical and lexical semantics of urban places are no longer suitable to kindle creativity and innovation. Logical semantics is more directly political since it refers to matters such as sense, presupposition and implication. Lexical semantics concerns the relation between words and meaning; it is more technical but it also helps to change the perception of objects especially as a communication tool.

A new taxonomy of urban places is meant to propose evocative "names" for the now so-called "non-places" (Augé 1995). We have been lingering on Augé's "non-definition" for too long a time. Thus, we have transformed a critical and potentially progressive classification and theory, which led to a new perception of urbanization, into an inert term. The analytical toolbox and the list of definitions used in the past are no longer compatible.

\section{A research on clean breaks in urban history}

Historical studies in geography and planning should focus on the cultural clean breaks that have occurred in the course of history and have led to different ideas of city and urban design. What we learnt in the past will unavoidably come back in our new thoughts, but we'd better minimize its influence and try to imagine a new beginning. As a matter of fact, a major hindrance to change is our being in love with what we have stored in our experience and the consequent aversion to leave it apart if not to forget it altogether. It happens in all fields of life, from relationships to jobs, from moving to a new house to sell the old car. The psychological resistance to change can be beneficial in as much as it helps to elaborate on new paradigms only when the old ones are ultimately torn and useless. It also compels innovators to submit dependable and consistent projects instead of just visionary conjectures. Equally, the obvious psychological resistance to change is detrimental when it stems from sloth or when fear of change is instrumental to the conservation of those entrenched power positions that innovators dare to challenge instead.

By calling for a new classification of human settlements, we move a step forward on a new way to perceive, define and eventually plan them. The call for assigning new names to metropolitan sites bears a highly political and ideological content. A new taxonomy will not thoroughly and immediately change urban policies, but to list new meaningful appellations for places that now have none and consequently we cannot even "see", favors midlong term transformations.

Geographers are in charge of activating this process, but they cannot accomplish the task alone and need to 
cooperate with scholars in linguistics, communication, administrative law and political studies. Because environmental risks are one of the major problems in the contemporary world, physical geographers and scholars in environmental studies would also help in the search and construction of the new urban taxonomy.

\section{Anthropocene and taxonomy}

Geographers and natural scientists are typically fascinated by taxonomy. In 2008 the Stratigraphy Commission of the Geological Society of London accepted at large majority that the proposal of making the "Anthropocene" (a newly coined term) a formal unit of geological epoch classification had some merit. Allegedly, we entered a new epoch when "human activities started to have a significant global impact on Earth's geology and ecosystems". Even before an official approval as a scientific category, the term had spread in many environmentalist publications and in media language (Gibson-Graham and Roelvink 2010).

A certain degree of skepticism is still healthy due to the obvious trouble in defining a geological era-shift while we are still living in it. It prompts a humorous novel by Lewis (1963), The Evolution Man, in which some highly evolved hominids keep wondering whether they are still in the Pleistocene or they have already moved forward into the Holocene. The idea that one can detect the passage from one epoch to another during a lifespan is clearly paradoxical and this constitutes one of the two ironies of Roy's novel. The other is that they already knew the names of geological epochs! On the other hand, it is not so absurd since the physical change of the planet's environment is taking place at a speed never encountered before. Moreover, if we assume that the change began approximately three centuries ago, at the dawn of the industrial revolution, we acknowledge that the phenomenon has already been active over a reasonably long period and across many generations, yet nothing compared with geological time.

One of the features of Anthropocene is clearly visible in the transformation of human settlements. Since a few decades ago, a classic starting point of urban analysis has been the distinction between population concentration and urbanization. The former is the physical clustering of billions of people in densely populated areas. The latter, namely the urbanization process, is a radical change in the division of labor, in economy and in society that involves human relations accordingly. Urbanization implies a clean break from people's dependency on local resources, mainly on food, and from the previous social-communitarian structure. This apparent radical change has not yet implied consequences in the language adopted to deal with urban themes. If a few new terms have entered the urban jargon, a systematic scholarly new lexicon is not yet available. A new vocabulary would help in implementing environmental protection and new lifestyle policies that fit in the Anthropocene.

\section{Classic urban sociology and geography}

At the foundation of classic urban sociology lies the nineteenth century Tönnies' key distinction between community (Gemeinschaft) and society (Gesellschaft). To a large extent it is the social complement of the country-vs.-city physical dichotomy, which mostly refers to the physical domain. In the same period, geographers and economists began to study human settlements and offered a systematic taxonomy for several types of urban settlements, such as cities, towns, villages and hamlets. They provided definitions and thus ranked the settlements according to dimensions and functions. Social scientists focused on identifying regularities in the location and dimensions of human settlements. The most well-known location theories and models were elaborated by the German geographers and economists von Thünen, Alfred Weber, Christaller and Lösch who had many followers all over the world in the ensuing decades. These models-being part of the cultural positivist atmosphere of the time in which they were elaborated-aimed at offering an $a$ priori description of future developments. A posteriori it became clear how they also bore an implicit and almost unavoidable confusion between the "is" and the "ought to be". Due to the implicit prescriptive/desirable content of the approach, some practitioners and scholars adopted location theories and models in planning and interpretation until the end of the twentieth century and some still quote them occasionally.

Contemporarily, history-inspired geographers and statisticians studied how in reality the urban concentration process took place from the eighteenth century up to the end of the second millennium. In the sixties, through monumental research, Kingsley Davis tried to quantify the urban concentration process. He created such a sound analytical paradigm that scholars and international organizations still refer to his research and apply it to an urbanization phenomenon completely changed in its nature and physical form. In the nineteen-fifties and sixties, all over the Western world, the urbanization process became untamable. It deeply transformed the structure of urban settlements and the very meaning of them, including human relations in the physical space. Davis' research and most scholars accepted Hope Tisdale's classic and very popular (and quite simple if not naive) definition of urbanization that millions of students have been taught approximately until forty years ago. Tisdale stated: "Urbanization is a process of population concentration. 
It proceeds in two ways: the multiplication of points of concentration and the increase in size of individual concentrations". Clearly, neither this definition nor Kingsley's analytical units represent any longer the contemporary urban phenomenon. Calculating the physical concentration of people in so-called urban areas is quite irrelevant today because the urban lifestyle-as opposed to the rural self-sustained economy-is a generalized pattern: even in remote villages and areas, communication and division of labor imply both autonomy from local resources and information about larger areas and even global events; thus a sort of participation in larger communities.

While the modern use of the term "metropolis" had already been applied to a few world cities since the turn of the nineteenth and twentieth century, in 1960 Jean Gottmann introduced the successful definition of Megalopolis to indicate the recently-formed continuous urban area lying between Boston and Washington D.C. on the North-East coast of the United States. Later, the same phenomenon took place in other countries and became a typical settlement pattern. In 1966 the English geographer Peter Hall considered the Ruhr Gebiet and the Randstad Holland as "urban systems" formed by a network of small and mid-size towns that operated conjunctly so that, as a whole, they could be considered "world cities" in as much as classic metropolises such as London, Paris, New York, Tokyo and Moscow. However, the exceptional migration of people towards few urban areas spurred geographers and planners to formulate new terms to describe human settlement landscapes. Terms such as metropolitan areas, conurbations, attraction or gravitation poles, polarized or polycentric growth, became commonly used in urban and regional planning and soon also in the current language. It would be interesting to carry out research about the history of how urban settlements have been named, catalogued and classified in the last century or so.

In economics, scholars have also developed theories and analytical paradigms. The language of the urban economies of scale, the threshold analysis, the base and non-base activities, the company town vs. the unspecialized city alternative, still contributes to the vocabulary we use daily. Finally, Florida coined the successful term "Creative Class" that referred to innovators living in some hypothetical city or urban area.

The general trend has been seeing urban phenomena at a higher scale. Consequently, we named larger and larger compounds we had no terms to define yet. At the same time, we forgot about what was happening at the micro scale of neighborhoods and blocks. Therefore, why are we surprised if we lost control on what we are unable to see? Of course, it is possible that we do not see them just because they do not exist any longer, having been substituted by a dispersed society that does not identify with any place. This might be a condition that we need to get accustomed to and in which we are bound to live in the next several decades. Otherwise, it is also possible to wonder if we might not see them because we do not care to look at them. In this case we accept the current condition as unavoidable so that all we can do is minimize the problems in the short term. This conservative approach undoubtedly makes sense too; nonetheless in this paper I stand for a progressive approach.

\section{Some methodological clues}

Methodologically, it is worth keeping in mind how words and classifications that describe objects and phenomena include some unavoidable teleological content, no matter how much the researcher tries to be neutral and focuses on mere description. Geographers and social scientists-now even physicists accept that examined objects are influenced by the tools used to observe them-know that objective description is a chimera. This is of course a huge epistemological issue: in this essay, it is just worth mentioning rather than debating it. Contemporary urban geography needs to propose new definitions of human settlements, which both explain a consistent reality and help in pursuing some declared and largely shared goal. An effective and rigorous taxonomy is one that applies to most situations and facilitates dialogue among scholars who argue within a given framework. Thus, a new taxonomy is helpful if the large majority of the scientific community accepts it as the foundation of an open discussion. Because the names given to urban places are not value-free and the study is to a certain extent goaloriented, this operation is political.

I would be naively presumptuous if I immediately assigned definitions and names to settlements. This operation requires long and rigorous research and can't be a one-man undertaking as it implies a collective acceptance of the terms and of the epistemology that sustains new definitions. Therefore, with this essay I just want to inspire long-term research in this typical branch of geography.

\section{Part two: reality and perception of urban settlements \\ Change the scale}

In the last century migration occurred from rural areas to cities. People abandoned broad regions that now are almost uninhabited. Rural migrants, fleeing their villages and hamlets, moved into cities and towns whose population grew by several orders of magnitude, though we go on calling them by the name of the old tiny downtown 
where the political and administrative power has clustered since the middle ages or even antiquity. Usually the appellation we apply to the gigantic and sprawled urban areas constitutes less than one tenth, if not one twentieth, of the whole area we address with an ancient city name. Therefore, more than $90-95 \%$ of urban areas lack specific place names or they are irrelevant: who ever heard about Molenbeek before Brussels' 2016 terror attack? How many Paris banlieu (slums) can we list? We might mention alleged neighborhoods like London's Chelsea or New York's Brooklyn and yet we are speaking about millions of people and vast areas whose names derive from a previous tiny settlement and are still recognizable only in those few blocks. Besides the proper nouns of places and spaces, we are short of a list of urban typologies to define what we perceive as undifferentiated settlements.

Marc Augé brilliantly designated them as "non-places" (non-lieux) and proposed the so-called super-modernity theory. The non-place definition-"two complementary but distinct realities: spaces formed in relation to certain ends (transport, transit, commerce, leisure) and the relations that individuals have with these spaces (Augé 1995)"-has become popular among urban scholars since it portrayed properly both a shared physical geographical perception and the personal emotion of whoever traveled through such anonymous areas spotted with a few "transit sheds". Unfortunately, as has always been the case in the last forty or so years, the most successful new definitions of social and geographical issues convey a gloomy gist. Thus, "non-places" go happily along with terms such as "post-modern"-and post-everything indeed-deconstructionism, de-growth, relativism, liquid society, not to speak about Calvino's "invisible cities" that is the ultimate symbolic definition of the contemporary urban condition. Whoever formulated the unconstructive successful terms was looking backward and neglected to envision the future. All definitions have referred to the past. Mainstream geographical research does not seem interested yet in systematically elaborating tentative new definitions of urban places, classifying them by an original scheme and creating a new urban vocabulary by applying a historical, critical and humanist approach.

Because we call the cities by the name of the old historical town centers, all the other areas have no name and are perceived as an undifferentiated periphery.

\section{Urban disorder}

Too often, urban scholars have quoted Lorenzetti's frescoes in the Palazzo Pubblico (Town Hall) of the city of Siena (Italy). Hence, I promised I wouldn't ever refer to it again in my writings, this being quite a tedious quote. Alas, I cannot keep my promise because it inspires one more helpful consideration. Nonetheless my quotation goes the other way around compared to most of the previous commonplace quotations. Lorenzetti's picture focuses on the city and it typically shows the contrast between the city order as opposed to bad government and country disarray. This is how it used to be when cities were clearly self-contained political and social systems capable of defining their identity and possibly imposing their power on hinterlands.

Currently, cities have lost their specific power that has been transferred to states and federations, and even to an undefined, though all-encompassing system that governs-or perhaps does not govern-economic and social phenomena. The order the city once represented moved somewhere else, in a place that we can't detect, it being "de-territorialized" and "space-less". In Lorenzetti's Bad Government fresco scene, nothing fits as it should and the most evident feature is the conflict, which is taking place in wild countryside-a non-place-between two armies. The contemporary metropolis is much more similar to the Bad Government part of the triptych than to the more often quoted small and well-ordered town.

While city centers have elaborated several names for their sub-units, names sometimes rooted in history, such as arrondissements, contrade, boroughs, quarters and the likes, suburbs typically go unnamed. Some of the names of old villages that were assimilated in the urban sprawl are almost forgotten. Suburban toponyms often refer to agglomerations of more than one hundred thousand inhabitants living on large uniform areas.

\section{Urban rebellion}

Robin Hood and his Merry Men could hide well in the wilderness of Sherwood Forest. The Nottingham Sheriff's troops did not dare to enter the woods because they lacked enough knowledge of a geographical area they perceived as a uniform indistinct place. On the other hand, Robin's comrades knew every detail of the environment where they settled. Nottingham was inaccessible because the walls clearly and rationally defined it. Sherwood's runaways reacted to the inaccessibility of Nottingham by being no less unreachable but they adopted a different strategy: instead of tracing clear barriers they hid in an undefined place that they secluded notwithstanding its deceptive openness. The Forest was a nonplace as was Lorenzetti's countryside while nowadays it is the opposite: the city has become an unruly non-place while contemporary country is more structured both socially and physically.

There are no longer walls surrounding contemporary cities' historical centers or CBDs, but they are still clearly distinct from the suburbs both in reality and in people's perception. In the city centers, different rules apply: traffic regulations are different, motorized accessibility is 
limited, more public transportation is available. Furthermore, building policy promotes conservation and the entire city layout responds to a different organization.

\section{Part three: economics and governance in metropolitan areas}

In the contemporary world of mega-cities, more and more people perceive city oligarchs-lobby-controlled political representatives that Florida (2002) praised as if they really were a "creative class"-as a delegitimized if not utterly illegal power that has occupied the once-democratic grassroots institutions. People do not identify in a social class nor do they form a political mass that aggregates on a geographical basis. Indifferently they group according to lifestyles, occupations, ethnicity, religion, income and more. All these spontaneous and, to a large extent, unaware communities neither have a political status nor assume they should strive for it (Poli 2015, part 2 ). Most of the contemporary political values and institutions are based on the firm assumption that nothing is authorized to exist outside the legitimate society and its governments. A comprehensive society was the goal of the modernization process that, step by step, reduced the tolerance for the plurality of legal systems and for ethnic and religious diversities. Therefore, the existing city governments do not recognize the de facto communities in the urban sprawl and-what is even worse-communities themselves think they have no right or chance to be acknowledged (incorporated) in the current setting. In as much as inhabitants feel anonymous in the metropolises, they either grow a strong sense of belonging to smaller illegal and apparently oppressed communities, or become uninterested in any civic involvement. The lack of representation of geographical metropolitan communities is latent because the metropolitan system works fairly well most of the time. Or, to put it better, citizens are not yet completely aware of possible alternatives to contemporary urban settlement and design that communication technologies have made available long since. Therefore, they see a solution to the usual troubles in standard infrastructures and call for short-term responses.

\section{The misleading economic competitiveness of metropolitan areas}

Recently, the celebrated architect Renzo Piano proclaimed emphatically that "we need to reclaim urban peripheries". As a matter of fact, all over the world, decision makers have often hired famous architects to design outstanding buildings that seldom really transformed the surrounding shantytowns into better places. Piano's intention is certainly respectable, but it's doomed to disappointment if it lacks a deeper analysis. The very words Piano speaks forebode failure: "reclaim the peripheries".
Referring to generic peripheries is misleading. First, because you need to establish a center before defining a periphery and this is no longer easy. Second and consequently, because the first step to improve peripheries should be to disaggregate, identify and name parts of them and then operate on those more specific sections. Otherwise we still consider peripheries as something uniform and marginal as the etymology of the word spells. Periphery comes from ancient Greek ( $\pi \varepsilon \rho \iota \phi \varepsilon \dot{\varepsilon} \rho\llcorner\alpha)$ and means "all that lies around": sure, but around what if the center is missing or it is insignificant? This use of the word suggests grand and aimless projects, which is exactly what did not work.

The problem regarding the reclaiming of peripheries is mostly structural economic and it's a difficult one. A large and growing section of citizens are unhappy and very critical of the organization of the sprawled city and thousands of advocacy groups aggregate against typical issues such as the establishment of larger and more distant shopping centers, new throughways, land development and the like. But (a) the fulfillment of citizens' preferences, (b) a change in urban design and (c) the basic infrastructures needed to sustain a new approach to urban habitat would make a significant portion of the big companies that provide old-fashioned infrastructures less profitable. No surprise then that big companies hinder change. Being able to have their projects approved by political power, which they are interweaved with, they are not keen to invest in research and innovation.

We should not approach this problem as if it were a matter of dishonesty and deliberate cheating. On the contrary, because this is not a conscious attitude, we fail to discuss it on a rational basis. Corruption is a consequence rather than the cause of inefficiency. It depends upon a lack of political authority and initiative, and on the weakness of scholarly influence (Poli 2011). Because political and intellectual visions have been missing for a long time now, investors have become politically powerful and intellectually lazy. Sprawled settlements provide large mass markets that only oligopolistic companies can occupy by virtue of economies of scale that fit into the analytical paradigms that favored past development. Large shopping centers and more and more concentrated retail distribution companies are an emblematic feature of a power concentrated somewhere else, in a physical nameless space. The exaggerated dimensions of the brand names on the shopping centers' boards contrast with the anonymity of places and people (Gottlieb 2007, Poli

\footnotetext{
5 Paradoxically periphery has the same etymological meaning of "environment" (all the turns around) though the former is used in a derogatory sense in urban studies and the latter, which comes from Latin and French, shows a favorable condition.
} 
$\left.2009^{6}\right)$. Public economy, planning and management of large suburban areas function in the same logic: they also include the construction of mass transit, mobility infrastructures and housing, which require large-scale investments that only national and super national governments (e.g. EU) can provide.

Cities used to be places where "people lived" because they could find almost everything that they needed there. Civic institutions were born and are still perceived according to this deep-rooted social perception. On the contrary, contemporary urban areas are mostly places where people continuously "move around". Moreover, they not only move around physically, but telecommunications allow them to also roam virtually in cyberspace. The administrative and local government borders have not significantly adapted to this new situation. Governmental data collection procedures have not yet seriously taken into consideration the new relation between people and geography. It is highly unlikely that a simple retracing of administrative borders can solve the problem of reestablishing a connection between area, administration and citizenship. People move across several city borders daily: they sleep in one municipality, work in another, send children to a who-knows-where school and spend leisure time in another place. God knows-but administrators don't-how many city borders an average citizen crosses every single day! Because of the obsolescence and ineffectuality of administrative borders we accept the paradox that citizens vote only where they sleep, which is where they perform the least socially relevant activity and probably not the place where they spend most of their time! Provided there is a place where they really spend most of their time regularly!

\section{How to represent urban spaces}

Administrations and local governments employ conventional maps to render urban territories. Maps mainly report physical topography and cultural-political features. They contribute to preserve the traditional perception of urban space. Furthermore, data bases now in use rarely consider how economic relations, human interactions and the relation between humans and places have changed as a result of the diffusion of telecommunication

\footnotetext{
${ }^{6}$ Ray Bradbury (1953), in his celebrated novel Fahrenheit 451, gives us a striking picture of the suburban world: “I sometimes think drivers don't know what grass is, or flowers, because they never see them slowly," she said. "If you showed a driver a green blur, oh yes! he'd say, that's grass! A pink blur! That's a rose garden! White blurs are houses. Brown blurs are cows. My uncle drove slowly on a highway once. He drove forty miles an hour and they jailed him for two days. Isn't that funny, and sad, too? ... Have you seen the two hundred-foot-long bill -boards in the country beyond town? Did you know that once billboards were only twenty feet long? But cars started rushing by so quickly they had to stretch the advertising out so it would last".
}

and information technologies that are broadly networked and atomized. The structure of old cartography delays a possible radical change in the perception of the interaction between humans and the built environment. For example, the link between communication and transportation is losing importance and this process is likely to speed up in the future. Governments and municipal planning departments have digitalized cartography and routinely use GIS, but they still collect most of demographic data according to where people officially live rather than how they move and/or communicate. Therefore, digital maps showing virtual interactions are not yet applied to government, administration and planning. Well-developed techniques are available and pundits often present fascinating demonstrations at Conferences. However, most of the times, they are still meant as visual artwork rather than city managing tools (see, e.g., the MIT SenseableCity Lab's website). We need a profound reformulation of urban perception to apply digital maps that include virtual interaction to city government (including citizens' political participation). Unfortunately, the approach adopted by specialists in new database and in real-time monitoring of the city phenomena lack the cultural foundations that would allow them to propose a different idea of metropolitan areas.

It is correct, as MIT's SenseableCity Lab enthusiastically claims that "the real-time city is real! As layers of networks and digital information blanket urban space, new approaches to the study of the built environment are emerging. The way we describe and understand cities is being radically transformed-as are the tools we use to design them". The SenseableCity Laboratory "is characterized by an omni-disciplinary approach: it speaks the language of designers, planners, engineers, physicists, biologists and social scientists. SenseableCity is as fluent with industry partners as it is with metropolitan governments, individual citizens and disadvantaged communities. Through design and science, the Lab develops and deploys tools to learn about cities". The problem is that the starting point of this project is not in humanities, political studies and philosophy. In other words, technicians pose the problems and assume that the society should adapt to technology while, for a "real" and advantageous change we require to re-think the basic conditions of living together. MIT engineers and architects would not admit it, but-at least unconsciously-the order, in which the SenseableCity Lab lists the specialists involved is not casual and implies a decreasing ranking in importance of the disciplines listed. Moreover, they completely overlooked scholars in administration, geography and history, policy studies, psychology and philosophy, unless they consider them all included in all-purpose social scientists. The very word "omni-disciplinary" is 
naïve and makes little sense in epistemology. No doubt that SenseableCity data processing systems are necessary for a more efficient administration, but before using them we need to raise the right questions and propose a new urban perception to billions of urbanites.

\section{The failure of metropolitan governance}

City expansion did not only depend on the number of new inhabitants. The so-called urbanized areas spread across even broader territories due to the diffusion of fast and flexible mass transit infrastructures and private cars.

It was not technology that deterministically caused such a development. It was rather caused by a mix of political philosophy and the consequent economic convenience. The liberal idea of free movement and free market was fascinating to people who once used to dwell in circumscribed compounds. Territories and citizens were separated by hard-to-cross borders and forced to pay tolls wherever they wanted to go and whatever they liked to trade. When the new ideas took over, the dominant thought was that we could and ought to claim the right to free movement. Then, each single citizen considered themselves entitled to have access to any merchandise or service no matter how far they were located. This philosophical and economical demand was satisfied by the transformation of cities where people lived in, into areas where people move around. Technology and industry responded to this demand. Once the transportation companies grew up to huge dimensions and a complex system was put in motion, then the growing process became self-generated. This observation implies that a change in philosophy-whose political dangers I do not overlook at all-and in consumers' preferences might imply a new change in technology and in urban movement policies.

The enlargement of cities absorbed minor centers, towns and villages. This new phenomenon cancelled out the hierarchical settlement network-the one studied by the 19th and 20th century German geographers and economists quoted above-and effaced the meaning of century-old (if not millennia) toponyms. The reaction was intellectually passive: politicians and planners simply planned larger and larger urbanized areas conjointly by transferring authority from the grassroots to some comprehensive regional government. Thus, in the seventies, "metropolitan planning" flourished as an academic discipline and section of administration. Incidentally, this attempt was less successful than expected.

With the exception of a few brilliant (and well-advertised) cases of metropolitan planning, the reason behind an almost generalized failure depended on a lack of representation and political influence of the area that was to be planned. "Metropolitan area" was and is nothing but a blurred geographical expression, without any clearly-defined and influential government, constituency and representatives. Even fewer people perceive it as a (political, geographical) "place" to identify with. The city ruling classes, and the citizens they represent, could deal directly with national or federal governments. Metropolitan areas are usually fragmented into several governments that are occasionally (in the U.S.) not even incorporated. Not only do the metropolitan local governments rule over small areas that are defined by old borders, which in Europe most of the time date back to the middle ages, but they are also insignificant because they no longer correspond to mobility patterns and everydaylife requirements. Thus, there is no legitimate power in metropolitan areas except the distant national or even federal government. No one has ever raised the following question: can we really govern metropolitan areas? If we consider it possible to simply apply the standard city government scheme to a larger area and that size does not matter, the answer is affirmative. It is negative, instead, if we think that size matters and over a certain geographical and demographic dimension we need a completely different approach to area administration. Extended metropolitan areas are no longer simple enlargements of the city: substantially, they are something else and rather resemble Robin's Sherwood or Lorenzetti's bad government scene which represents wilderness. In less allegorical terms, what was once thought of as urban expansion is indeed a nameless area whose growth no longer depends on the city. People settling in large metropolitan areas are not there because the city needs them. On the contrary, it is a self-fertilizing oxymoronic "dispersed concentration" process out of any real control of legitimate authorities and consequently impossible to plan. Many non-legitimate powers operate in the sprawled metropolitan areas so that they are like lands to colonize and exploit, noman's lands like the American West or aboriginal Australia. Therefore, there are no "metropolitan" citizens because there is no local metropolitan recognition and government Only national or federal governments really matter.

On one hand, newly established regional authorities proved scarcely effective in planning the new settlements. On the other hand, all technology, and the industrial and professional lobbies that promoted their implementation, developed in order to manage enlarged urban areas that ultimately came down to one single issue, namely mobility. Mobility and traffic are not the sole problems created by urban expansion. Housing, retail distribution, micro-criminality, neighborhood community relations and more, have been affected by the massive immigration into urban areas. Nonetheless, governments tackled most of emergencies by simply improving mobility infrastructures: initially just roads, later mass transit 
infrastructures. Problems as diverse as inefficient retail distribution, lack of jobs, overcrowded schools, poor health care and the likes became merely mobility issues. If something was not available in the neighborhood, governments were called to provide easy access to it, instead of attempting to make it available locally. Also, citizens (and mainstream scholars) have learnt to see problems through the deforming lenses of this available solution instead of elaborating a possible alternative perception of the area where they lived. Urban rent fostered metropoli$\tan$ expansion, but the latter was not "urban-planned"; rather it was "transportation-planned".

This universal approach to urban growth problems implied large and expensive infrastructures. Small government units could neither finance them nor could they agree on the projects. A typical and often-applied strategy was to wickedly pit one municipality against the other so that eventually the central government was entitled to make an authoritarian decision against the will of dissenting local governments and citizens. Thus, in the name of the greater good and with the consensus of most of the voters, national or federal governments were able to intervene to finance metropolitan infrastructures by draining resources from the rest of the country. The obvious consequence is more concentration of power and a further subjugation of the suburbs, which generates more and more unruly, unnamed dwellers. The larger the local government, the more it is intrinsically intertwined with national and federal governments (which in Europe includes EU). But the essential problem is that the established administrative philosophy-which is inspired by a strict relation between people, area and administrationhas gone awry.

In the last decades and due to the globalized economy, local governments have lost most of their powers so that Mayors are often the caciques of central oligarchies. An urban secession, as it was theorized in the recent past by some scholars and activists, has become unlikely nowadays. Because local governments are typically in charge of urban planning, there is little hope that we can offset the ongoing "slummification" of the metropolitan areas and the loss of control of their uncontrollable people. ${ }^{7}$ There is nothing we can do immediately to change this situation by using traditional means that can range from a democratic approach and political activism to straightforward violent rebellion, from technocratic and rationalist design to institutional engineering. A long term, but effective and viable, strategy to challenge the entrenched

\footnotetext{
${ }^{7}$ The cases of slums' rebellions - that now and then show up on the front pages of newspapers and have been masterly depicted in the Cannes' prizewinner French movie "La haine" - are not even the most critical part of the anonymous and unruly mood of the suburbanites.
}

power system and people's misled and impoverished perceptions is just cultural, namely we may propose a different vision that a new urban language can politically promote. An original new terminology would also speed up a further progress in a full application of ICTs. Until now, ITC just overlaid the existing social, mental and organizational structure and has not yet impacted on it as deeply as it might have.

\section{The political problem}

You don't just need an architect, no matter how famous, to change the peripheries. A new metropolitan design and governmental arrangement would challenge the economic structure and the governing oligarchy, which is now intertwined with-if not thoroughly controlled bythe corporative lobbies. The cases of slum rebellions that now and then show up on the front pages of newspapers are not even the most critical part of the anonymous and unruly mood of the suburbanites. The authentic long lasting rebellion is the people's detachment from politics and citizens' participation a kind of innere Emigration, that is the distancing of several German intellectuals from politics, although they continued to live in Nazi Germany. Pity it is hopeless and quite cowardly. Sometimes governments face protest groups that oppose issues such as a new land development, the establishment of a new shopping center, pollution from a hazardous plant or the construction of a new highway. Occasionally, it happens that local interest groups form when a higher rank (municipal, national, federal, and more likely the three together) government wants to implement a project in the logic of a metropolitan rationality that clashes with local interests. This aggregation of people is typically ephemeral and does not even lead to self-recognition as a political subject of change.

City oligarchs try to take control and curb the free, but defiant and disordered, spirits of the suburban world. The growing populism and the consequent rise of charismatic national leaders are one of the effects of suburban uniformity and namelessness. In Robin's Sherwood, Richard the Lion Heart was the legitimate leader by birthright and alleged rectitude, but no one had ever personally met him before. Likewise, contemporary populist leaders legitimate their power thanks to anything-but-democratic tools, namely the rhetorical empty narrative of general (or better generic) elections celebrated nationwide. The same alienating emptiness shows when a million plus people elect the Mayor of a huge metropolis. An illusory consensus forms on national and international media, certainly not in the grassroots that are out of reach and control. Suburban people never have the chance to discuss local and general political issues in caucus-like institutions or at the local offices of political 
national parties. Local leaderships of traditional parties are missing and no longer originate from the grassroots, as was sometimes the case in the past. The large nameless territory lying around the (metaphorical) citadels of oligarchic power is hard to subjugate. Nonetheless it can still be both exploited as a market and ignored politically.

\section{Marginalization of the middle-class}

Metropolitan anonymous sprawl hides all sorts of marginalized people. Odd to say, but as proven by political voting behavior, it is also the middle and upper middleclass who are most aloof from political activism or from structured institutional representation. Their lack of political involvement implies an unconscious unhappiness and a hopeless expectation for a simple and quite miraculous solution that a charismatic leader would incarnate. The concept of middle class is per se obsolete in the new metropolitan world: it's not the income that characterizes the social group and the standard of living. With $€ 40,000$ per year you are definitely not rich, yet you have the possibility to choose among diverse lifestyles and allocate your money in different ways and give your life some meaning. The same happens if you make $€ 200,000$ per year: you are almost rich, but your lifestyle is not necessarily related to your money since you can still invest in a huge urban mansion or in traveling and education or God knows what, maybe even in a selfsustained bio-farm. In contemporary society for a growing section of the population, money-more precisely money-making meant as a proxy of success in life-is a secondary aspect in adopting a lifestyle (Viard 2011, Ray and Anderson 2000). Moreover, there are several public goods-such as clean air, easy communications, road safety, environmental quality in general-that cannot be bought and several risks are evenly shared by the rich and the poor. Governments and political processes in Western countries are unable to satisfy this major social demand since the political system, the dominant ideology and the economic tools have been engineered to respond to different basic needs.

\section{The name of the city}

As per the arguments exposed above, a primary issue concerns the opportunity, if not the necessity, to have a truer coincidence between citizens and places, area and administration. On one hand, we have de-territorialized human relations since technology allows interacting intensely with other people wherever you are physically located. On the other hand, because of the same telecommunication development, we have the opportunity to stay longer in the same place and so we need to make that place enjoyable, to make it home. But that place has no name yet, hence it is invisible! Civic institutions should follow and encourage this possible trend that reduces pollution, energy demand and environmental impact of infrastructures needed to move. A new list of place names and typologies of urban spaces would help in promoting environmental and social consciousness.

\section{Borders and boundaries}

Modern urban planners assume that city borders are no longer necessary and the grid should have no limits to expansion. In the sprawled settlements, the characters and the identity of the areas included in the expansion of the city are meaningless because what really matters is the general conceptual (intangible) design.

You do not realize exactly when you truly enter the metropolis because the transition is incredibly stretched, and there's no clear sign that separates "in" from "out". In principle, this responds to a democratic criterion of indifference to place, as opposed to the many variances that characterized medieval cities, specifically tolls, laws, government, social segmentation. Lacking city limits, citizens and administrators approach problem-solving by enlarging, instead of nurturing what is already available. Consequently, when we move to a geographical analysis of the city, the sprawled settlement vs. the walled city dichotomy can be synthesized in two types of edges that can be either "boundaries" or "borders". Sennett, using a biological language, says that the former are like "cell walls", fit to contain and separate what's in from what's out. The latter resemble "cell membranes" that are typically both porous (penetrable) and resistant. Membranes are not simply open doors, but work out the balance between porosity and resistance. That combination of porosity and resistance is a spatial precondition for cooperation between people who differ (Sennett 2011). The modern urban ideal of free but solitary individuals was a goal for rural people who wanted to escape ghettoized and prescriptive communities. The urban society is now largely at work, but modern individuals now react to solitude and try to form new diversities and strive to be part of groups. Hence, we now speak of a society fragmented in "lifestyle communities" that do not have yet any territorial correspondence (Viard 2011).

In urban sprawl, the characters and identity of the areas which are included in the deceptively unregulated expansion of the city are meaningless. There is indeed a design, but it is concealed because it is the consequential outcome of a series of intangible philosophical principles (or just biases) that are passively and unconsciously applied. What seems to be a practical and spontaneous urban development is instead sustained by a formidable ideology. "All that is solid" does no longer melt "into the air" and the concrete flood cast over green lands is the outcome of abstract thinking and engrained beliefs. 
Economic laws enforced by powerful companies mastermind city form. Citizens and administrators attack empty space, or better a space they perceive as empty. When not-so-educated Europeans-as I was in my twenties-travel in the U.S. or in Australia, they are surprised to see how many native and aboriginal toponyms are still around in a completely urbanized and western milieu. It means that something was there before the city expansion, but it also means that it was treated as just open and meaningless space to occupy. The link between former real places to which the names were given and the new settlement has been completely lost. However, the old native "names" prove that there were "places" that colonizers did not really see and overlaid the city grid and western culture over them.

The same we can say regarding the names of natural places: in the modern and contemporary modern city, we have separated nature from the built environment. A typical example is gated urban parks. Even more evident is the attempt to hide all that is natural by digging or concealing creeks, cutting trees, pouring concrete on natural lawns. No surprise then if natural geographical names have disappeared. The problem is that other names are not available yet: we've run out of words to name places.

In the medieval town, there are gardens merging with the people and their dwellings; the stones buildings are made of come from the region so that their color integrates with the landscape; finally, the very architecture and building design recalls springs, heights, caves, meadows, glens etc. However, the most important characteristic of medieval towns is that they are small and dependent on the countryside lying around them. Thus, some European areas-such as Tuscany, Provence or Flandershistorically developed a highly developed urban culture, although they were founded on a plurality of small and mid-size centers merged with the natural/agricultural landscape. Therefore, Sennett's question: "how can we design spaces in the city which encourage strangers to cooperate?" should be integrated with another question: "how can we design urban spaces which create a stronger link between humanity and nature?" A different relationship between humanity and nature lends itself more to creating the conditions for cooperation by reproducing "porous" borders.

\section{Part four: the geographer's solution}

\section{What to do? The geographer's solution}

Because urban geography is essentially "writing about the city", geographical research includes a linguistic content. It means that to describe an urban landscape you need both logical and lexical semantics. Analysis and description are not neutral in identifying goals and problems' solutions. By writing about what they see, geographers allow the observer to see places never seen before. Places cannot be seen because the observer's eye did not know how to think about them as nobody yet described them. To render never-before-seen places, we need words, phrases and texts that convey specific meanings. In this respect, the geographer's explanation is creative and fundamental to address planning and systematically open planners' perspectives.

Consequently, the uniform urban sprawl must be catalogued and disassembled into parts to which we assign multiple names by trying to identify the latest differences and original settlement typologies. Then it is possible to give the new components of the urban sprawl their own name. Finally, we can mention those places and begin to refer to them customarily. In the past, geographers catalogued villages and towns, cities and metropolises; in all languages, there are numerous names given to different kinds of urban settlements. The proper names' origin may be historical, architectural or civic, but most of them reconnect with specific typologies that have lost meaning in the recent generalized urbanization. Thus, linguists and geographers should try to define places according to parameters such as human density, functions, building styles, some physical geographical aspect, environmental issues, social and economic activities etc. Differently from what western settlers did in the new world, we need to detect and name the existing places and so appreciate them.

The rebellious Sherwood was uniform and unknown to the Nottingham Sheriff's troops: it was just a generic Forest. Instead, Robin's merry men knew how to distinguish and refer to many places such as meadows, groves, creeks, glens, brooks, canyons, orchards, glades to which they could give proper names. And, much more than this, they could move around without getting lost because they could see the differences.

This is neither an easy nor an overnight task. It requires attention to places' details that do not have a name and a definition so that, by naming them, we will factually create them. It involves a "conscience of the eye" to detect them and a linguistic imagination to label places with proper words rooted in language and history. The conscience comes from a different approach applied to assess the value and the meaning of the existing places.

Only well trained and-in as much as possible-unbiased observers can do it. They are writers who have seen a lot and are still surprised when they run into places they keep seeing from diverse perspectives and can create new emotional names. Rigorous linguistic research and well-developed communications skills are necessary to coin meaningful and successful new terms. If by systematic and creative observation and definition we succeed in inventing difference in the otherwise uniform 
urban spaces we can proceed to the next step, that is to assign planners and architects a rigorous mission. It is normal that long-standing taxonomies and definitions all too often outlive the goals they were created for. Thus, in urban geography we now speak a conservative and trivial language: urban policies follow accordingly. It's time for a linguistic and paradigmatic revolution: in Kuhnian's terms, the old paradigms and words have been used and are now depleted; therefore, they cannot properly describe contemporary milieus. This is a small first step, but it is exactly what we need to start a long journey with a well-defined direction. This seemingly conjectural move is likely to ignite the fuse of a chain reaction.

Renaming city spaces may have a crucial effect on administration too. In urban sprawl, administrative territorial subdivisions are irrelevant from a historical, social and economic point of view. No surprise then if they do not help an efficient ruling and management. Even in politics, the lack of a solid relation between people, area and administration implies the necessity to reconsider the entire local government structure and representation of people which also includes taxation.

\section{Conclusion}

We do not want to be unhappy "post-moderns" forever and we rather aim at becoming enthusiastic "harbingers" of the new urban world to come. Thus, I call for geographic and linguistic research whose goal is to return to definitions. New definitions may be required for the alleged entering in the new Anthropocene geological epoch. Finally, human and historical geography as a discipline and well trained geographers will once again play a specific role that they abdicated long ago by engaging in theoretical issues or adopting a sociological approach.

"What's in a name? That which we call" an anonymous urban area "by any other name would look as" indefinite. A name cannot change the city and our connection with places. However, new terms for now-nameless sites would help to change people's perception and their capability of seeing what they never saw before. The taxonomic geographer's call for assigning new names to metropolitan sections' typologies implies a political and ideological content. This is a radical approach and, in fact, it may become utterly rebellious!

\section{Authors' contributions}

Not applicable.
Consent for publication

I consent for publication.

Ethics approval and consent to participate

I-sole author-consent to participate and approve the journal's ethical code.

Funding

I declare that my research and writing has not been funded by any Institution or organization.

Received: 9 February 2017 Accepted: 26 April 2017

Published online: 05 May 2017

\section{Reference}

Augé M (1995) Non-places: introduction to an anthropology of supermodernity. Verso, New York

Berman M (1982) All that is solid melts into air. Simon and Schuster, New York Bradbury R (1953) Fahrenheit 451. Ballantine, New York (NY)

Cross Disciplinary Urban Space (2016). http://crossdisciplinaryurbanspace.com

Crozier M, Friedberg E (1980) Actors and systems: the politics of collective actions. University of Chicago Press, Chicago

Florida R (2002) The rise of the creative class. Basic Books, New York (NY)

Gerschenkron A (1962) Economic backwardness in historical perspective. Harvard University Press, Cambridge

Gibson-Graham JK, Roelvink G (2010) An economic ethics for the anthropocene. Antipode 41(s1):320-346

Goodchild D (2004) The validity and usefulness of laws in geographic information science and geography. Ann Assoc Am Geogr 94(2):300-303

Gottlieb R (2007) Reinventing Los Angeles: nature and community in the global city. MIT University Press, Cambridge (Mass)

Gottmann J (1961) Megalopolis. The urbanized northeastern seaboard of the United States. The Twentieth Century Fund, New York

Habermas J, Luhmann N (1971) Theorie der Gesellschaft oder Sozialtechnologie-Was leistet die Systemforschung?. Suhrkamp, Frankfurt

Hall P (1966) The world cities. World University Library, Weidenfeld and Nicolson, London

Hall P (1988) Cities of tomorrow. Basil Blackwell, Cambridge (Mass)

Harvey D (1969) Explanation in geography. Edward Arnold, London

Lewis R (1963) The evolution man. Penguin, London

Myrdal G (1968) An Asian drama: an inquiry into the poverty of nations. Twentieth Century, New York

Poli C (2009) Città Flessibili. Una rivoluzione nel governo urbano. Instar Libri, Torino (Italy)

Poli C (2011) Mobility and environment. humanists vs. engineers in urban policy and professional education. Springer, New York

Poli C (2015) Environmental policy. New geographical and political constituencies. Springer, New York-London

Ray PH, Anderson SR (2000) The cultural creatives. Harmony Books, New York

Rostow W (1960) The stages of economic growth: A non-communist manifesto. Cambridge University Press, Cambridge

Sennett R (1990) The conscience of the Eye. Knopf, New York (NY)

Siu D (2004) Tobler's first law of geography: a big idea for a small world? Ann Assoc Am Geogr 94(2):269-277

Smith J (2004) Unlawful relations and verbal inflation. Ann Assoc Am Geogr 94(2):294-299

Viard J (2011) Nouveau portrait de la France. Éditions de l'aube. La Tour d'Aigues, La societé des modes de vie

Acknowledgements

Not applicable. 